\title{
TOWARDS TO A SINGLE INNOVATION SPACE IN THE AGRARIAN SECTOR OF THE MEMBER STATES OF THE EURASIAN ECONOMIC UNION: A CASE STUDY
}

\author{
Andrey Paptsov ${ }^{1 *}$, Vasiliy Nechaev², Pavel Mikhailushkin ${ }^{3}$ \\ ${ }^{1,2,3}$ Federal Research Center of Agrarian Economy and Social Development of Rural Areas - All Russian Research \\ Institute of Agricultural Economics, 123007, Khoroshevskoe shosse, 35k2, Moscow, Russia \\ E-mails: ${ }^{*}$ info@vniiesh.ru
}

Received 18 March 2019; accepted 15 July 2019; published 30 September 2019

\begin{abstract}
The article deals with the formation of a single innovation space in the agrarian sector of the member states of the Eurasian Economic Union with the aim of rational use of their total scientific potential. The approaches to the formation of a common innovative space of the EU countries are considered. A distinctive feature of the modern stage of development of the innovation space in the agro-industrial sector of the Eurasian Economic Union is the intensification of cross-border cooperation of the participating countries. Models of interstate cooperation in the scientific and technical sphere were developed and a "panel of indicators" for the development of the market for scientific and technical products was proposed. Practical recommendations are given on innovation transfer in the agrarian sector of the economy of the member states of the Eurasian Economic Union. The economic effect will be manifested in increasing the volume and competitiveness of agricultural products, increasing the yield of agricultural producers, increasing the volume of innovative products and their share in the global agri-food market.
\end{abstract}

Keywords: Eurasian Economic Union (EAEU), innovation space, models of interstate cooperation, "panel of indicators".

Reference to this paper should be made as follows: Paptsov, A.; Nechaev, V.; Mikhailushkin, P. 2019. Towards to a single innovation space in the agrarian sector of the member states of the Eurasian economic union: A case study, Entrepreneurship and Sustainability Issues 7(1): 637-648. http://doi.org/10.9770/jesi.2019.7.1(45)

JEL Classifications: F02, F01, Q01

\section{Introduction}

Effective innovative development in the framework of integration requires a common focus and mutual coordination of the innovation activities of the countries participating in the integration association. The cooperative, synergistic effect of innovative development with integration is associated with the possibility of using various forms of interaction - the creation of common funds, pilot sites, the implementation of joint projects, clustering of organisations belonging to academic and non-academic sectors etc. (Asaliev et al., 2014 a,b; Tvaronavičienè, Razminienè, 2017; Ivanova et al., 2018).

The EU experience confirms that the common EU innovation space has common goals and principles of functioning within the framework of economic integration. At the same time, national innovation systems of European countries are considered separately from the common space and have their own characteristics (Asheim, Coenen, Moodysson, Vang, 2007).

There is no single model for the formation of the innovation space. It is specific for each country and is shaped by the national specifics of economic, industrial and regional development (Johnson and Hinton, 2019). For example, France implements in its innovative development the policy of "poles of competitiveness", i.e. the creation of specialized innovation clusters with state priority, which is not typical for developed industrial countries (Les labellisations des pôles depuis, 2005). In the UK, innovation centres are created to develop specific technologies and promote them to the market (for example, Printable Electronics Technology Centre, PETEC) or for a specific sector of the economy or market (Korableva and Kalimullina, 2014; Bentahar and O'Brien, 2019; Zavyalova, 2018; Puryaev, 2015; Mueller et al., 2019). Such centres are considered as strategic drivers of economic development at the regional level (Ministry of Economic 
ENTREPRENEURSHIP AND SUSTAINABILITY ISSUES

ISSN 2345-0282 (online) http://jssidoi.org/jesi/

2019 Volume 7 Number 1 (September)

http://doi.org/10.9770/jesi.2019.7.1(45)

Development of Russia. Reference on the International Experience of Innovative Development). The use of the results of scientific and technical activities and intellectual property in the agrarian sphere of the member states of the Eurasian Economic Union (hereinafter referred to as the EAEU) serves as the basis for the production of competitive products in the agro-industrial complex of the Union countries, ensuring their food safety. The relevance of the study determines the need for the formation of a single innovative space, and, consequently, the market of agricultural scientific and technical products of the EAEU member states. In the course of studying the possibilities of forming a single innovation space in the Eurasian Economic Union, the authors used the following methods: abstract-logical, monographic, economic-statistical, balance, expert assessments.

\section{Results}

The "single innovative space" of the EAEU member states should be understood as the territory where a single complex of economic, innovation and legal events is held. This category should not be identified with an "innovation sphere" - the area of activity of producers and consumers of innovative products (works, services), including the creation and distribution of innovations (Zhuravlev et al., 2018; Korableva et al., 2018; Ladatko and Nechaev, 2005, p. 30).

A single innovation space in the agrarian sector of the EAEU member states has not yet been formed, although the Recommendation of the EEC Board (hereinafter referred to as EEC) (dated February 19, 2013) No. 3 "On the Need to Prepare the Procedure for Developing and Recommending Intergovernmental Programs within a Single Economic Space" and the Decision of the Collegium of the EEC of July 8, 2015. No. 14, which highlighted promising areas for R \& D until 2020, were adopted (Recommendation of the Board of the Eurasian Economic Commission of February 19, 2013, No. 3; Recommendation of the Board of the Eurasian Economic Commission of July 8, 2015, No. 14).

The formation of a single innovation space is directly related to the implementation of the goals and objectives presented in the programs and development strategies of the agro-industrial complex of each EAEU member country (Concept of the Strategy of Innovative Development of Armenia; The Concept of Innovative Development of the Republic of Kazakhstan until 2020; Science and Innovation Activities in the Republic of Belarus; The Main Directions of the Strategy for Sustainable Socio-Economic Development of the AgroIndustrial Complex of the Russian Federation for the Period up to 2030; Development of the Agro-Industrial Complex and Cooperation).

The authors support an approach towards formation of a single innovation space in the agrarian sector of the EAEU member states, which claims that success of such attempts directly depends on digitalization replacing analogue (physical) data collection and processing systems with technological systems that generate, transmit and process a digital signal about their condition (Lincaru et al., 2018; Pogodina et al., 2019, Order of the Government of the Russian Federation dated July 2, 2017 No. 1632-p; Strategy for the Scientific and Technical Development of the Russian Federation until 2035).

Digitalization will affect all existing markets, including markets for innovative products, since they will all have a networked nature, which will have a positive effect on the growth of labour productivity in the industry (Gamede and Uleanya, 2018; Kamolov et al., 2019; Hanfan and Setiawan, 2018; Polyakova et al., 2019). At the same time, one of the main distinguishing features of the current stage of development of the innovation space in the agro-industrial sector is the intensification of cross-border cooperation, by analogy with the European Union. As an example of such interaction, the creation of a cross-border cluster (RussiaKazakhstan) on deep processing of grain, which the authors considered in the previous works, should be given (Nechaev and Mikhayushkin, 2017; Nechaev et al., 2017; Kolpak et al., 2017; Barmuta et al., 2017; Dzhavatov et al., 2018; Dunets et al., 2019). 
ENTREPRENEURSHIP AND SUSTAINABILITY ISSUES

ISSN 2345-0282 (online) http://jssidoi.org/jesi/

2019 Volume 7 Number 1 (September)

http://doi.org/10.9770/jesi.2019.7.1(45)

It is the effectiveness of their development, and not only in the border areas but also abroad, that will, in the future, determine the positions of the EAEU member states in the agrarian sector of the economy, not only in the domestic but also in the global agri-food markets. The result of this cross-border cooperation will be: the expansion of the sales market for agricultural products based on innovative technologies, the development of a competitive environment, the creation of new jobs, the growth of export revenues from the sale of competitive products in the domestic and foreign markets, and the inflow of investments in the agricultural sector (Ponomareva et al., 2019). The formation of a single innovation space in the agrarian sphere of the EAEU member states is hampered by a number of problems:

- lack of supranational coordination of scientific, technical and innovation potentials, identifying the interests of the countries-partners for cooperation, identifying strategically possible technological spheres in them for the development of joint innovation projects;

- the high cost of this process in the formation of the interstate space coordinating the potential of innovation systems of cooperation partners in the global scientific, technical and educational space;

- imperfection (absence) of the model of integration relations in science, technology and financial policy, which makes it necessary to delegate part of the national authority to a supranational level (by analogy with the EU);

- the continuing contradictions of the national interests of the EAEU Member States in the market for innovative products;

- adverse global conjuncture in the agricultural market for scientific and technical products (price fluctuations, changes in demand, credit restrictions, the financial instability of all members of the Union);

- lack of a system for training scientific personnel for interstate innovation cooperation, innovation infrastructure, entrepreneurship in the scientific and technical sphere, investment mechanisms and other development institutions.

At the same time, there is an objective expediency of forming a single innovative space in the agricultural sector of the EAEU member states in order to optimize the use of scientific and financial resources to ensure the sustainability of the market for scientific and technical products in order to stimulate mutually beneficial innovative development of national agro-industrial complexes of the Union countries.

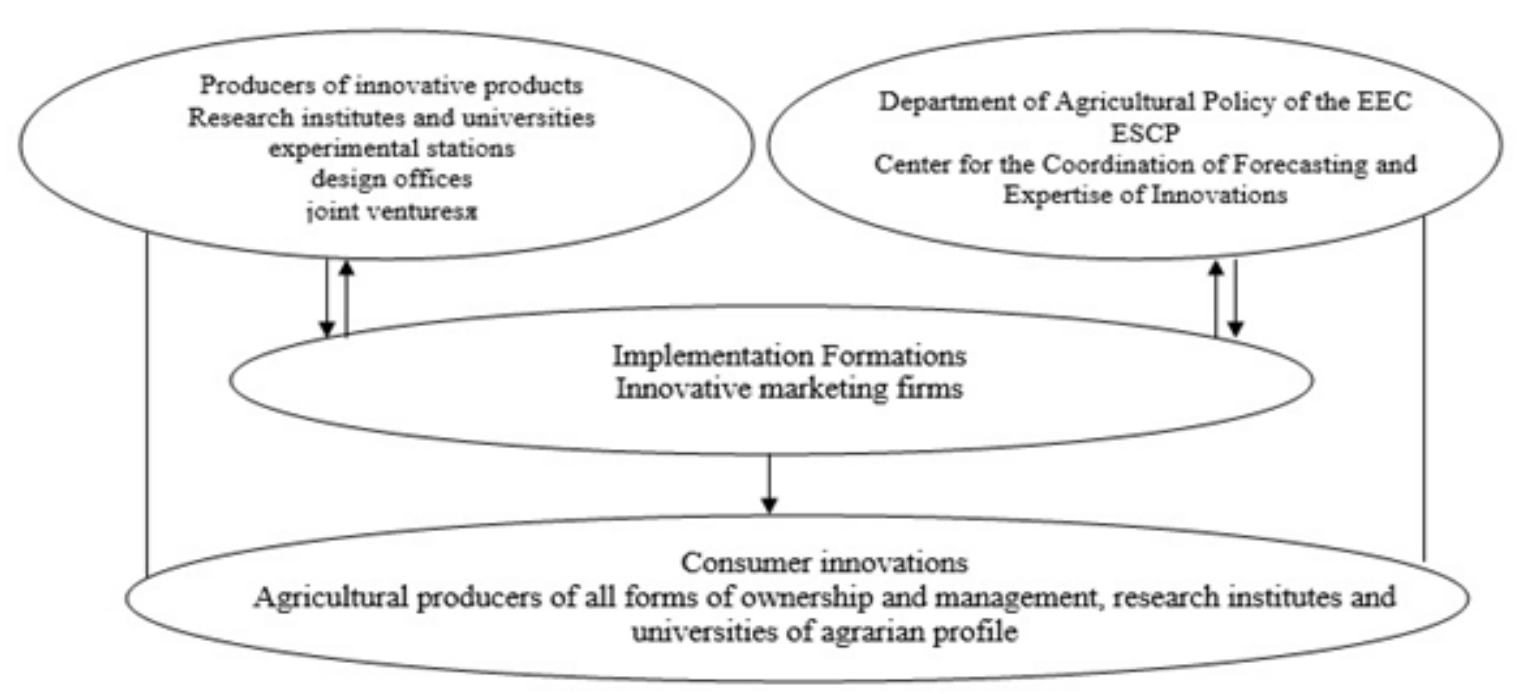

Fig.1. Conceptual model of the innovation market in the agricultural sector of the EAEU member states Source: Research Report, 2017

The Eurasian Agricultural Technological Platform created in accordance with the decision of the Eurasian Intergovernmental Council of April 13, 2016 No. 2 "Regulations on the Formation and Functioning of Eurasian Technological Platforms" and facilitating cooperation in the scientific and technological and innovation spheres based on the unification of the scientific and financial potentials of the states of the Union, 
ENTREPRENEURSHIP AND SUSTAINABILITY ISSUES

ISSN 2345-0282 (online) http://jssidoi.org/jesi/

2019 Volume 7 Number 1 (September)

http://doi.org/10.9770/jesi.2019.7.1(45)

effective interaction of all interested parties (business, science, government, and intergovernmental organizations) in order to stimulate mutually beneficial innovative development of national agrarian complexes, constant technological renewal of production and increase the competitiveness of their products (Decision of the Eurasian Intergovernmental Council of April 13, 2016 No. 2).

The further formation of interstate innovation space can be carried out on the basis of models of interstate cooperation. The conceptual model of the innovation market in the agrarian sector of the EAEU member states is presented in Figure 1. In the presented model, on the polar sides there are the producers of innovative products and their consumers - agricultural producers of all forms of ownership, as well as the organizations of the science itself: research institutes and educational institutions of the agricultural sector. Based on the experience of various integration associations, and in accordance with the Recommendation of the EEC Board dated February 19, 2013 No. 3 and the Decision of the EEC Board of July 8, 2015. No. 14 to create and master the achievements of scientific and technological progress, it is advisable to create interstate research structures (Recommendation of the Board of the Eurasian Economic Commission of February 19, 2013, No. 3; Recommendation of the Board of the Eurasian Economic Commission of July 8, 2015, No. 14).

The functional model of the research and production interstate formation within the EAEU is presented in Figure 2.

At the stage of development and use of the model, it is planned to create several functional blocks:

- research and production coordination;

- development of production and sales of finished innovative products based on network technologies;

- production of high-quality agricultural products;

- production of finished products based on innovative technologies (resource-saving and environmentally friendly);

- development of market infrastructure for the sale of finished products in the markets of the EAEU and third countries.

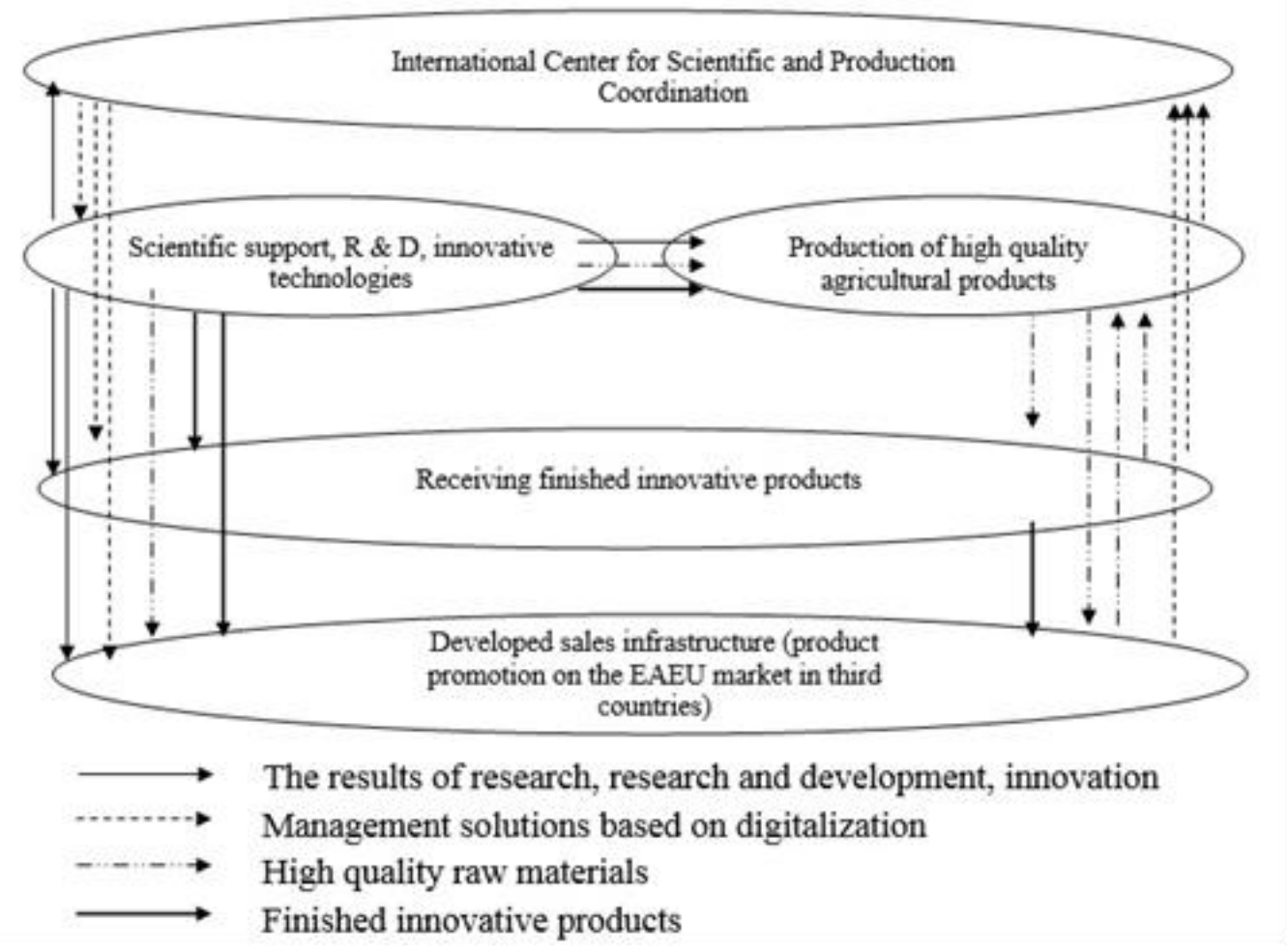

Fig.2. Functional model of a research and production interstate formation within the EAEU Source: Research Report, 2017 
ENTREPRENEURSHIP AND SUSTAINABILITY ISSUES

ISSN 2345-0282 (online) http://jssidoi.org/jesi/

2019 Volume 7 Number 1 (September)

http://doi.org/10.9770/jesi.2019.7.1(45)

It should be noted that as of January 1, 2016, 65 joint ventures and more than 40 organizations with foreign capital operate in the agrarian sector of the EAEU member states. Their field of activity is focused on the production of potatoes, vegetables, livestock products, their processing, as well as the provision of various types of services (Research Report, 2017).

The mechanism of interaction of participants in interstate innovative entrepreneurship in the agricultural sector is presented in Figure 3. This mechanism is characterized by a complex interstate structure and consists of a set of models of innovative entrepreneurship, as well as two main blocks - organizational and economic. The main priorities of the organizational block of interaction of participants in interstate innovative entrepreneurship should include the creation of a supranational centre under the auspices of the Eurasian Economic Commission (hereinafter ECE) to coordinate innovative developments and introduce them into production (Darin and Telyakov, 2017; Telyakov et al., 2016), indicative planning and coordination of R \& D, training innovative managers, creating information and consulting and marketing firms (Prodanova et al., 2019b; Sadriev \& Mullakhmetov, 2016; Suratno, 2018; Takhumova et al., 2018; Zagrivnyi et al., 2019).

The economic block of interaction of participants in interstate innovative entrepreneurship in the agrarian sphere includes: interstate support based on the creation of a single financial fund to subsidize a part of interest rates on loans received for creating, acquiring and introducing innovations into the real economy of the EAEU member states; preferential taxation and insurance of risky (venture) innovations in the territory of a single innovative space; common approaches in pricing innovative products; leasing of scientific and technical equipment and other financial and economic methods and tools at the interstate level.

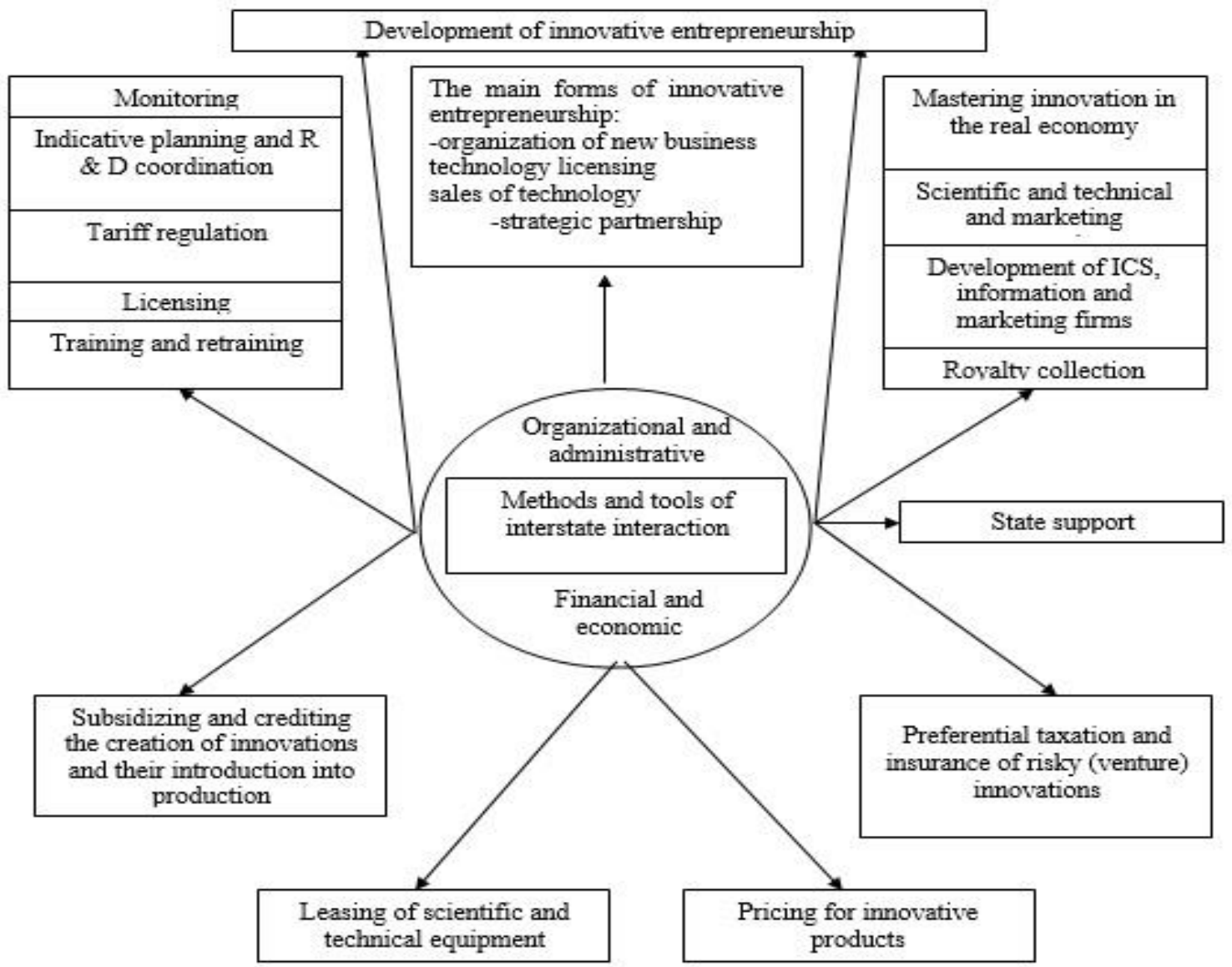

Fig.3. Mechanism of interaction between participants in interstate innovative entrepreneurship in the agricultural sector of the EAEU member states

Source: Research Report, 2017 
ENTREPRENEURSHIP AND SUSTAINABILITY ISSUES

ISSN 2345-0282 (online) http://jssidoi.org/jesi/

2019 Volume 7 Number 1 (September)

http://doi.org/10.9770/jesi.2019.7.1(45)

The development of interstate cooperation to form a single innovative space in the agrarian sector of the economy of the EAEU member states should be carried out in stages, starting with the creation and development of institutions and mechanisms for expanding the market for scientific and technical products and unhindered movement of capital and technology (Osadchy, 2015; Goloshchapova et al., 2018; Prodanova et al., 2019a; Voronkova et al., 2019). To this end, a market infrastructure should be formed as a priority - a set of institutions and organizations, consulting and information and marketing firms that ensure the free movement of scientific, technical and innovative products in the agricultural market.

It is the effectiveness of their development, as well as the degree of participation of the EEC in creating a favourable business environment in the future, that will determine the position of the EAEU member states in the global market for scientific and technical products (Malarev et al., 2018). In this regard, it will be useful for the EAEU member states to use the experience of the development of integration processes in the European Union based on the use of interstate agreements for the implementation of joint innovation projects. At the present stage of development of a single innovative space of the EAEU member states, it is proposed to limit the creation of a number of intergovernmental non-governmental organizations, among which the International Agrarian Scientific Society of the Union countries and the International Association "AgroEducation" should be noted. The first type of organizations is created to prepare for the EEC recommendations for the development of the market for scientific, technical and innovative products; the second is designed to assist educational institutions in fulfilling the tasks of staffing and scientific support for the development of the agro-industrial complex of the EAEU member states; maintain close ties with interstate and public organizations; study and distribute advanced foreign experience of the best educational, research and educational institutions; prepare innovative managers to work in the conditions of creating a single innovative space of the EAEU member states.

Particular attention should be paid to the development of practical methods of transferring innovations to the agro-industrial production of the Union countries on the basis of an agreed set of price (discounts, bonuses), financial (deferred payment, instalments for a long period, leasing), credit (subsidizing interest rates), technical (maintenance and repair in the regions of supply of equipment), as well as the use and improvement of the mechanism of public-private partnership in the promotion of advanced innovative developments in the agricultural sector of the Union economies.

The basis of the innovation space in the agrarian sector of the economy of the EAEU member states, along with the national innovation systems, is the market for scientific and technical products (STP), which should be understood as the totality of intellectual property objects, market agents, legal mechanisms, and information means by which the price level of the STP is formed and acts of sale are carried out. Currently, in the countries of the EAEU, the STP market is not developed and requires the direct and indirect influence of the state and intergovernmental authorities for its improvement proposed by the authors (Mikhailushkin et al., 2018; Ladatko and Nechaev, 2005; Nechaev, 2018; Yemelyanov et al., 2018; Ilyina et al., 2019; Polyakova et al., 2018).

In order to manage the STP market and carry out its quantitative assessment, the authors used the "panel of indicators" of the development of the market for scientific and technical products in the agricultural sector of the EAEU member states, presented in Figure 4, which allows assessing the current state of this market in the context of international trends (National Report on Innovations in Russia, 2017). 


\section{PANEL OF INDICATORS OF DEVELOPMENT OF THE STP MARKET IN THE AGROINDUSTRIAL COMPLEX OF THE EAEU MEMBER COUNTRIES}

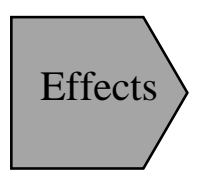

\section{The quality of life Cost effectiveness}

- Lifespan

- Ecological efficiency
- Labour productivity

- Energy efficiency of production

\section{Competitiveness}

- Global leadership in the STP market

- Global competitiveness of STP

- Favourable business conditions

\section{Security}

- Food Security

- Cybersecurity

\begin{tabular}{|c|c|c|c|}
\hline & Research and development & Commercialization & STP \\
\hline Results & $\begin{array}{l}\text { Publications } \\
\text { - Country share in WOS scientific } \\
\text { publications } \\
\text { - Citation of WOS scientific publications } \\
\text { Patent applications } \\
\text { - Patent activity } \\
\text { - Country's share in the global flow of } \\
\text { patent applications } \\
\text { - Share of foreign patent applications }\end{array}$ & $\begin{array}{l}\text { - Technology } \\
\text { - Country share in current patents } \\
\text { - Technology revenue } \\
\text { - Share of technology exports in } \\
\text { agriculture GDP } \\
\text { - Volumes of venture investments in } \\
\text { agriculture } \\
\text { - Share of venture capital investment in } \\
\text { agricultural GDP }\end{array}$ & $\begin{array}{l}\text { - Market share of the new } \\
\text { STP } \\
\text { - Cost effectiveness of } \\
\text { STP } \\
\text { - STP share in national } \\
\text { merchandise exports }\end{array}$ \\
\hline
\end{tabular}

\section{Financial and material}

- The volume of government spending on research and development in agriculture

- Percentage of research and development costs in agricultural GDP

- Share of business in research and

Resources $\bullet$ Volumes of total expenditures for agricultural research and development - Percentage of total R \& D expenditures in GDP for agriculture - Proportion of equipment capital costs in total costs

\section{Supply and demand of STP}

- Share of business in the costs of research and development of the state sector of science

- The share of the cost of acquiring new technologies in the cost of technological innovation

- Available venture funds

- Number of start-ups

\section{Cooperation of science and business}

- Proportion of agricultural organizations involved in scientific cooperation

- Cooperation of business and universities in research and development

\section{Innovative activity}

- The share of STP costs claimed by the business - Proportion of organizations producing technological innovations

- Expenditures of agricultural organizations for the purchase of STP

\section{The role of the state}

- Share of agricultural enterprises introducing technological innovations at the expense of the budget

\section{Staffing}

\section{The quality of education}

- Proportion of government spending on agricultural education in GDP

- Proportion of university graduates in demand on the labour market

Framework conditions
- Proportion of people with higher education in agricultural production

- Quality of education for business assessment

- Adult share in continuing education

\section{Quality science}

- Percentage employed in agrarian science - Share of publications in the agricultural sector in international collaboration in WOS and Scopus

- Quality of scientific organizations for business assessment

Fig. 4. Panel of indicators of the development of the market for scientific and technical products in the agricultural sector of the EAEU member states

Source: National Report on Innovations in Russia, 2017 


\section{ENTREPRENEURSHIP AND SUSTAINABILITY ISSUES}

ISSN 2345-0282 (online) http://jssidoi.org/jesi/ 2019 Volume 7 Number 1 (September) http://doi.org/10.9770/jesi.2019.7.1(..)

In the presented "Panel of Indicators" all indicators are grouped as follows: according to the stages of the development of the NTP market (horizontally); by levels of innovation space (vertical).

For most indicators of the impact of innovation on the economy and society, including the growth rates of labor productivity and life expectancy, Russia still lags behind the leading innovation economies. The country has not yet become a global leader in high-tech markets, domestic products are characterized by insufficient competitiveness.

There are negative dynamics in the development of research and production cooperation, gaps between science, education and business persist: the share of domestic industrial enterprises participating in joint research projects has decreased 1.1 times in the last two years, in general, for the period 2010-2017 years - 1.3 times. In the long run, there is no significant improvement in Russia in terms of indicators characterizing the results of commercialization (although, for example, the country's share in the total number of active patents among 45 countries has increased, but the de facto situation cannot be considered satisfactory).

\section{Conclusion}

The formation of a single innovation space in the agrarian sector of the EAEU member states on the basis of models of interstate cooperation will allow solving an important interstate problem of ensuring the access of the Union's agricultural producers to advanced agricultural technologies. Such an approach will help the countries to gain real economic effect from combining scientific and financial potentials, ensure mutual economic interest and build on this basis a mutually beneficial strategy for sustainable socio-economic development of the agrarian sector of the EAEU member countries on the basis of innovation. The achieved results of such cooperation would allow keeping decent positions both in the domestic and global agri-food markets.

\section{References}

Asaliev, A. M., Poltarykhin, A. L., \& Alkhimenko, O. N. (2014a). Intellectual capital: Theory and approaches of its assessment on macro level. World Applied Sciences Journal, 30(10), 1404-1408. http://doi:10.5829/idosi.wasj.2014.30.10.14187

Asaliev, A. M., Zhuravlev, P. V., \& Alkhimenko, O. N. (2014b). Intellectual capital management as the aspect of upgrading of modern companies management. Life Science Journal, 11(SPEC. ISSUE 11), 363-366.

Asheim B., Coenen L., Moodysson J., Vang J. (2007). Constructing knowledge-based regional advantage: implications for regional innovation policy. International Journal of Entrepreneurship and Innovation Management, 7, 140.

Barmuta, K.A., Yakovenko, Z.M., Zadorozhnaya, L.I., Mironov, D.S., \& Klochko, E. N. 2017. Advantages of cluster approach in managing the economy of the Russian federation. International Journal of Applied Business and Economic Research, 15(23): 355-364.

Bentahar, A., O’Brien, J. L. (2019). Raising students' awareness of social justice through civic literacy. Journal of Social Studies Education Research, 10(1), 193-218.

Concept of the strategy of innovative development of Armenia. Retrieved from http://iidf.am/docs/concept-innov-armenia.pdf 


\section{ENTREPRENEURSHIP AND SUSTAINABILITY ISSUES}

ISSN 2345-0282 (online) http://jssidoi.org/jesi/ 2019 Volume 7 Number 1 (September) http://doi.org/10.9770/jesi.2019.7.1(..)

Darin, A. A., \& Telyakov, N. M. (2017). Processing of ferromanganese concretions with the use of sulfatising roasting. Journal of Engineering and Applied Sciences, 12(5), 1113-1115.

Decision of the Eurasian Intergovernmental Council of April 13, 2016. №2 "Regulations on the formation and functioning of the Eurasian technological platforms"

Decision of the Eurasian Intergovernmental Council of April 13, 2016. №2 "Regulations on the formation and functioning of the Eurasian technological platforms"

Development of the agro-industrial complex and cooperation / Sustainable Development Strategy of the Kyrgyz Republic for 2018-2040. [Electronic resource] http://cbd.minjust.gov.kg/act/view/ru-ru/61542

Development of the agro-industrial complex and cooperation / Sustainable Development Strategy of the Kyrgyz Republic for 2018-2040. Retrieved from http://cbd.minjust.gov.kg/act/view/ru-ru/61542

Dunets, A. N., Ivanova, V. N., Poltarykhin, A. L. 2019. Cross-border tourism cooperation as a basis for sustainable development: a case study. Entrepreneurship and Sustainability Issues, 6(4), 2207-2215. https://doi.org/10.9770/jesi.2019.6.4(45)

Dzhavatov, D.K., Sverdlikova, E.A., Sokolov, M.S., Avdeeva, O.A., \& Yavkin, G.P. 2018. The influence of innovation on social and economic development of the Russian regions. European Research Studies Journal, 21(Special Issue 2): 767-776.

Gamede, B.T., \& Uleanya, C. 2018. Entrepreneurship: Solution to unemployment and development in rural communities. Journal of Entrepreneurship Education, 21(Special Issue)

Goloshchapova, L. V., Plaskova, N. S., Prodanova, N. A., Yusupova, S. Y., \& Pozdeeva, S. N. (2018). Analytical review of risks of loss of profits in cargo transportation. International Journal of Mechanical Engineering and Technology, 9(11), 1897-1902.

Hanfan, A., \& Setiawan, A.I. 2018. Exploiting regio-centric product advantage to increase small and medium enterprises' (SMEs) marketing performance. International Journal of Economics and Business Administration, 6(2): 3-26.

Ilyina, I., Kulibanova, V., \& Teor, T. 2019. Special aspects of master data-based integrated management of region reputation in modern IT environment. Paper presented at the IOP Conference Series: Materials Science and Engineering, 497(1) http://doi.org/10.1088/1757$\underline{899 X / 497 / 1 / 012022}$

Ivanova, V. N., Atyukova, O. K., \& Poltarykhin, A. L. (2018). Prerequisites of growth of investment and social attractiveness of the regions of russia within the framework of implementation of the public-private partnership projects. International Journal of Mechanical Engineering and Technology, 9(11), 2299-2305.

Johnson, C., \& Hinton, H. (2019). Toward a Brillant Diversity. Journal of Culture and Values in Education, 2(1), 56-70. Retrieved from http://cultureandvalues.org/index.php/JCV/article/view/27

Kamolov, S. G., Artemova, P. V., \& Berezko, V. E. 2019. Shaping the systems of digital public governance of the digital economy in Russia and abroad. Studies in Computational Intelligence, 826: 435-442. http://doi.org/10.1007/978-3-030-13397-9_51

Kolpak, E. P., Sulimova, E. A., Kireev, V. S., Samarina, E. A., \& Solodilova, N. Z. 2017. Clustering as a criterion for the success of modern industrial enterprises. International Journal of Applied Business and Economic Research, 15(23): 221-231.

Korableva, O. N., \& Kalimullina, O. V. 2014. The formation of a single legal space as a prerequisite for overcoming systemic risk. Asian Social Science, 10(21), 256-260. http://doi.org/10.5539/ass.v10n21p256

Korableva, O. N., Kalimullina, O. V., Zaytseva, A. A., \& Larionov, A. I. 2018. Elaboration of database for the subject domain of innovation and economic growth potential. Paper presented at the Proceedings of the 31st International Business Information Management Association Conference, IBIMA 2018: Innovation Management and Education Excellence through Vision 2020, $6065-6073$.

Ladatko, O. V., Nechaev, V. I. 2005. Intellectual Property from A to Z: Handbook. Printing House of the Kuban State Agrarian University, Krasnodar, p. 701. 


\section{ENTREPRENEURSHIP AND SUSTAINABILITY ISSUES}

ISSN 2345-0282 (online) http://jssidoi.org/jesi/ 2019 Volume 7 Number 1 (September) http://doi.org/10.9770/jesi.2019.7.1(..)

Les labellisations des pôles depuis. 2005. http://competitivite.gouv.fr/la-politique-des-poles-depuis-2005/les-labellisations-des-poles-decompetitivite-476.html

Lincaru, C., Pirciog, S., Grigorescu, A., Tudose, G. (2018). Low-Low (LL) High Human Capital Clusters In Public Administration Employment - Predictor for Digital Infrastructure Public Investment Priority - Romania Case Study. Entrepreneurship and Sustainability Issues, 6(2), 729-753. http://doi.org/10.9770/jesi.2018.6.2(18)

Malarev V.I., Kopteva A.V., Koptev V.Yu. 2018. Electric Power Supply System Development for Down-hole Electric Steam Generators to Produce High-viscosity Oil. International Multi-Conference on Industrial Engineering and Modern Technologies, FarEastCon. http://doi.org/10.1109/FarEastCon.2018.8602954

Mikhailushkin, P. V., Lubkova, E. M., Shilova, A. E., Zhuravlev, P. V., Karpenko, E. Z., \& Nikiforov, S. A. (2018). Possibilities of agriculture competitiveness increasing. International Journal of Mechanical Engineering and Technology, 9(11), 1401-1412.

Ministry of Economic Development of Russia. (2019) Reference on the international experience of innovative development http://economy.gov.ru/minec/about/structure/depSvod/doc20110407_02

Mueller, J. E., Chikunov, S. O., Fedchenko, E. A., \& Pronskaya, O. N. 2019. Innovative technologies in entrepreneurship education: The case of European and Asian countries. Journal of Entrepreneurship Education, 22(1)

National report on innovation in Russia. 2017. https://www.rvc.ru/upload/iblock/c64/RVK_innovation_2017.pdf

Nechaev, V. 2018. The organizational and economic mechanism of the functioning of the NTP market in the agroindustrial complex of the EAEU member countries. Economics of Agriculture of Russia, 8: 85-93.

Nechaev, V.I, Mikhayushkin, P.V, Slepneva, T.N. 2017. New approaches to the deep processing of grain based on the formation of an interstate cluster. Economics of agricultural and processing enterprises, 9: 52-55.

Nechaev, V.I., Mikhayushkin, P.V., Altukhov, A.I. 2017. Formation of a cross-border agro-industrial cluster of EAEU countries for deep processing of grain. Strategy for the development of the agricultural sector of the economy: problems and solutions. Collective monograph. Krasnodar: Enlightenment-South, p. 703c.

Order of the Government of the Russian Federation of July 28, 2017 No. 1632-p Program "Digital Economy of the Russian Federation" [Electronic resource] Access mode: http://static.government.ru/media/files/9gFM4FHj4PsB79I5v7yLVuPgu4bvR7M0.pdf

Osadchy, E. A. 2015. The intellectual capital importance and the role of organizations against the backdrop of a crisis: Innovation vector. Social Sciences (Pakistan), 10(6): 1013-1020. http://doi.org/10.3923/sscience.2015.1013.1020

Polyakova, A. G., Goloshchapova, L. V., Rakhmeeva, I. I., Noeva, E. E., \& Rakovskiy, V. I. 2018. A model of regional economic space modernization. European Research Studies Journal, 21(Special Issue 2): 624-634.

Polyakova, A. G., Loginov, M. P., Serebrennikova, A. I., \& Thalassinos, E. I. 2019. Design of a socio-economic processes monitoring system based on network analysis and big data. International Journal of Economics and Business Administration, 7(1): 130-139.

Pogodina, T.V., Aleksakhina, V.G., Burenin, V.A., Polianova, T.N., Yunusov, L.A. (2019). Towards the innovation-focused industry development in a climate of digitalization: the case of Russia, Entrepreneurship and Sustainability Issues, 6(4), 1897-1906. http://doi.org/10.9770/jesi.2019.6.4(25)

Ponomareva, N. V., Zvereva, A. O., Golubtsova, E. V., \& Ilyashenko, S. B. (2019). Tax incentives for use of alternative energy sources in the russian federation. International Journal of Energy Economics and Policy, 9(4), 144-148. http://doi.org/10.32479/ijeep.7964

Prodanova, N. A., Plaskova, N. S., Bochkareva, N. G., Babalykova, I. A., Gazizyanova, Y. Y., \& Zherelina, O. N. (2019a). Integrated Corporate Reporting as An Innovative Business Reporting Model. International Journal of Engineering and Advanced Technology, 8(5), 2075-2078. 


\section{ENTREPRENEURSHIP AND SUSTAINABILITY ISSUES}

ISSN 2345-0282 (online) http://jssidoi.org/jesi/ 2019 Volume 7 Number 1 (September) http://doi.org/10.9770/jesi.2019.7.1(..)

Prodanova, N. A., Trofimova, L. B., Adamenko, A. A., Erzinkyan, E. A., Savina, N. V., \& Korshunova, L. N. (2019b). Methodology for assessing control in the formation of financial statements of a consolidated business. International Journal of Recent Technology and Engineering, 8(1), 2696-2702.

Puryaev, A. S. 2015. The mathematical apparatus of compromise of efficiency estimation of investment projects. International Business Management, 9(5): 856-861. https://doi.org/10.3923/ibm.2015.856.861

Recommendation of the Board of the Eurasian Economic Commission dated February 19, 2013 N 3 "On the need to prepare the procedure for the development and implementation of intergovernmental programs within the Common Economic Space" [Electronic resource] Access mode: https://www.alta.ru/tamdoc/13rk0003/

Recommendation of the Board of the Eurasian Economic Commission No. 14 dated July 8, 2015 "On the list of promising research and development activities in the field of the agro-industrial complex of the member states of the Eurasian Economic Union until 2020" [Electronic resource] - Access mode: http://www.garant.ru/products/ipo/prime/doc/71025632/ (Appeal date: 16.01.2019)

Report on research work. Development of promising directions and mechanisms for the development of a coherent agro-industrial policy of the member states of the Eurasian Economic Union, including the field of interstate cooperation and import substitution. Stage 3. Preparation of proposals for the creation of models of interstate cooperation, networks and infrastructure in the promising for the cooperation sector of the agro-industrial complex, on the mechanisms of their interaction and evaluation of their effectiveness. Under the contract number H-12/171 dated September 16, 2016, Moscow, 2017. p. 46

Sadriev, R. D., \& Mullakhmetov, K. S. (2016). Russian business medium: Competition problems. International Journal of Economics and Financial Issues, 6(8Special Issue): 30-38.

Science and innovation activities in the Republic of Belarus. (Statistical collection) [Electronic resource]. - Access mode: http://www.belstat.gov.by/ofitsialnaya-statistika/publications/izdania/index_8305/

Suratno, A.P.S. 2018. Effect of government investment and capital participation on local own-source revenue: The case of Indonesia. European Research Studies Journal, 21(4): 368-377.

Takhumova, O. V., Kasatkina, E. V., Maslihova, E. A., Yumashev, A. V., \& Yumasheva, M. V. 2018. The main directions of increasing the investment attractiveness of the Russian regions in the conditions of institutional transformations. Espacios, 39(37)

Telyakov, N. M., Darin, A. A., Telyakov, A. N., \& Petukhov, A. A. (2016). Influence of the specific character of the content of ironmanganese concretions of the Pacific Ocean and Baltic Sea on technological indicators of valuable component extraction. Tsvetnye Metally, 2016(2), 40-45. http://doi.org/10.17580/tsm.2016.02.06

Tvaronavičienė, M., Razminienė K. 2017. Towards competitive regional development through clusters: approaches to their performance evaluation. Journal of Competitiveness, 9(4), 133 - 147, https://doi.org/10.7441/joc.2017.04.09

The concept of innovative development of the Republic of Kazakhstan until 2020 (adopted in 2012) [Electronic resource]. - Access mode: http://adilet.zan.kz/rus/docs/P1200000990

The main directions of the Strategy for sustainable socio-economic development of the agro-industrial complex of the Russian Federation for the period up to 2030. M: OneBook.ru, 2018. p. 58

The strategy of the scientific and technological development of the Russian Federation until 2035 [Electronic resource] http://sntrrf.ru/upload/iblock/c80/Decree $\% 20$ President $\% 20 \mathrm{P} \Phi \% 20 \mathrm{o} \% 20$ Strategy $\% 20$ scientifictechnological $\% 20 \mathrm{development} \% 20 \mathrm{Russia} \%$ $\underline{20 \text { Federation }}$

Voronkova, O. Y., Iakimova, L. A., Frolova, I. I., Shafranskaya, C. I., Kamolov, S. G., \& Prodanova, N. A. (2019). Sustainable development of territories based on the integrated use of industry, resource and environmental potential. International Journal of Economics and Business Administration, 7(2), 151-163.

Yemelyanov, V., Yemelyanova, N., \& Nedelkin, A. (2018). Diagnostic system to determine lining condition. Paper presented at the MATEC Web of Conferences, 172 http://doi.org/10.1051/matecconf/201817204001 


\section{ENTREPRENEURSHIP AND SUSTAINABILITY ISSUES}

ISSN 2345-0282 (online) http://jssidoi.org/jesi/ 2019 Volume 7 Number 1 (September) http://doi.org/10.9770/jesi.2019.7.1(..)

Zagrivnyi E. A., Malarev V.I., Kopteva A.V. 2019. Studying the Operating Mode of the Down-Hole Electrode Heater for the Production of High-Viscosity Oil. Proceedings of the 2019 IEEE Conference of Russian Young Researchers in Electrical and Electronic Engineering, ElConRus pp. 1110-1113. http://doi.org/10.1109/EIConRus.2019.8656868

Zavyalova, N. 2018. BRICS soft power promotion: Dataset for media preference and use pattern among the Russian audience who follow the development of BRICS. Data in Brief, 16: 939-946. http://doi.org/10.1016/j.dib.2017.12.004

Zhuravlev, P. V., Poltarykhin, A. L., Alkhimenko, O. N., \& Kuksova, O. D. (2018). Human capital and its efficiency in the knowledge economy: The role of continuing education. Espacios, 39(46)

\section{Andrey PAPTSOV}

ORCHID ID: 0000-0003-0605-3341

Vasiliy NECHAEV

ORCHID ID: 0000-0002-2294-7188

Pavel MIKHAILUSHKIN

ORCHID ID: 0000-0003-1304-8102

Register for an ORCID ID:

https://orcid.org/register

Copyright (C) 2019 by author(s) and VsI Entrepreneurship and Sustainability Center

This work is licensed under the Creative Commons Attribution International License (CC BY).

http://creativecommons.org/licenses/by/4.0/

c) (i) Open Access 